【カテゴリーIII】

\title{
明治初年に大坂城址に設置された近代的諸施設について ON THE MODERN FACILITIES ESTABLISHED IN THE OLD SITE OF THE OSAKA CASTLE IN THE EARLY YEARS OF MEIJI
}

\author{
橋寺知 子*, 川道麟太郎** \\ Tomoko HASHITERA and Rintaro KAWAMICHI
}

\begin{abstract}
The Osaka Castle was burnt down at 1868 , and the owner of the site was transferred to the Meiji new government from the Tokugawa feudal government. In the early years of Meiji, the state of the old site of the castle changed drastically. In that site, some modern buildings with the Western style were constructed and some new facilities were established by using old Japanese buildings. Their buildings and facilities were military, educational, and medical ones. Military use and civil use had coexisted side by side in the site at the beginning years of Meiji.
\end{abstract}

Keywords : the Osaka Castle, old site of the castle, early Meiji, land use, modernization 大阪城、城址、明治初年、土地利用、近代化

はじめに

大坂城は慶応 4 年（1868 年）の 1 月に焼け落ち、大坂城址とな って新政府軍の手に落ちた。同月に征討大将軍仁和寺宮嘉彰親王が 薩摩・長州簐を従えて大阪入りをし、大久保利通が「大阪遷都論」 を建議し、さらに 3 月には明治天皇が大阪に行幸し滞在した。また、 兵部大輔になった大村益次郎は、大阪に陸軍の拠点を開こうと考え ていた。これらのため、大阪はにわかに新国家建設のために注目さ れる土地になる。このような中で、明治初年に、大坂城址に舎密局、 兵学寮、軍事病院など、日本の近代化を図る施設を設置することが 決められ、建設に移されていった。これらの施設については、それ ぞれ当時の先端的な施設でもあり、個別には研究もかなりある。し かし、それらが同時期に、大坂城址という同一の地域に設置された ものとして一体的に取り扱った研究はない。また、それらは竣成し たものの、激動する維新期の混迷の中で、短期間にその内容や管轄 を激しく変えていったため、それらの系統的で正確な把握は容易で はなく、既往の文献でもいくぶんの混乱が見られる。そこで、本研 究では、明治初年に大坂城址に設置された諸施設を包括的に取り上 げ、個別の諸施設に関する先行研究の成果を踏まえ、それに新たな 知見も加えて、それらの設置と変遷の状況を系統的に明らかにして おきたい。

1. 本論における「大坂城址」の規定
大坂城は、天正 11 (1583) 年に豊臣秀吉によって建設が開始され、 三の丸、総構をもつ大きな城郭であった。秀吉の没後、大阪冬の陣・ 夏の陣を経て城は荒廃したが、その後徳川将軍家の城として豊臣期 以上に壮麗な城に造り変えられた。江戸期の大坂は幕府の直轄地で あり、「天下の台所」と称されたように、日本の経済・流通の中心 として栄えた。現在一般に大阪城として認識されている堀に囲まれ た部分は、徳川期に完成した本丸と二の丸の部分である。豊臣期の 三の丸は、冬の陣により堀を失い一時荒廃したが、新たに市街地と して整備され、将軍に代わって城を預かる城代・定番・加番などの 役人たちの屋敷や奉行所などの役所が集まっていた。城郭を中心と して、関連する行政機関が周囲を取り囲み、城と一体となって機能 していたのである。図 1 は、幕末・文久年間の 1863 年頃の大坂城 付近の地図である。西側の上町や船場のように町人が居住する地域 と、「東町御奉行所」や「御城代屋敷」、「下屋敷」などの文字が読 みとれる旧三の丸地域とでは、街区の大きさや形状が異なり、街の 性格が違うことが見てとれる。徳川政権が崩壊すると、堀で区画さ れた本丸・二の丸だけでなく、その周囲の役人たちの屋敷や役所も その機能を失った。明治新政府はそれらの跡地を一体として利用し、 新たに各種の施設を設置していつたのである。

このような観点から、本研究では、「大坂城址」を、徳川期の本 丸と二の丸に豊臣期の三の丸を加えた区域として規定する”。地図 上で示すと図 1 および図 2 の一点鎖線で囲んだ区域であり、現在の
* 関西大学工学部建築学科 専任講師 - 博士 (工学)

** 関西大学工学部建築学科 教授.工博
Lecturer, Dept. of Architecture, Faculty of Engineering, Kansai University, Dr. Eng. Prof., Dept. of Architecture, Faculty of Engineering, Kansai University, Dr. Eng. 


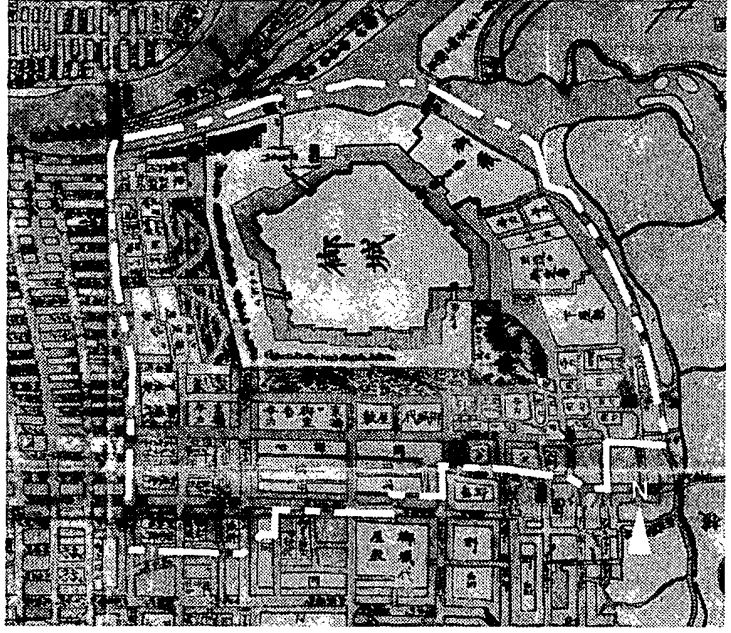

図 1 幕末の大坂城周辺

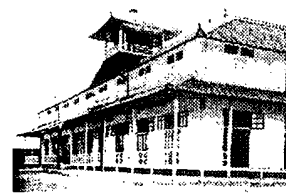

写真 1 舎密局

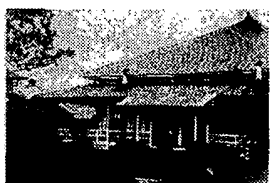

写真 3 ハラタマの住居

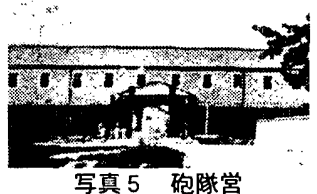

写真 5 砲隊営

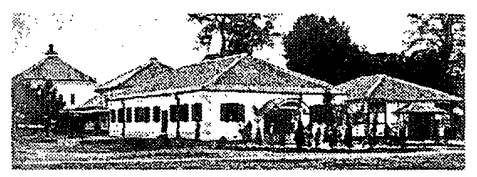

写真 2 大阪府医学校病院

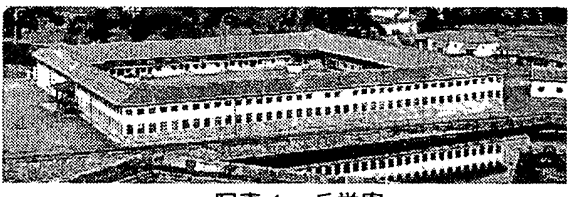

写真 4 兵学寮

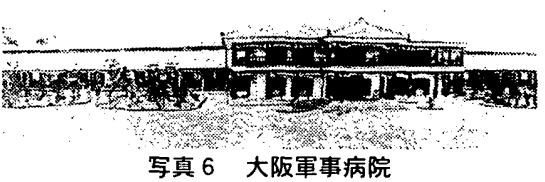

地名等を使って記述すると、西の境界は谷町筋（筋東側沿道の民家 用地の部分は除く，北は大川と平野川、東はJR 環状線（旧猫間川）、 南は龍造寺町・上町・法円坂 1 丁目のそれぞれの境界で囲まれた区 域となる。

\section{2. 教育施設の設置}

近代化に向けて、計画が早くから具体化したのは教育施設であ つた ${ }^{21}$ 。西洋の科学技術の導入はすでに幕末から始められ、西洋の 学術を教授する学校の設置が江戸幕府や先進的な諸藩によって進め られていた。維新後もそれらの事業の多くが明治新政府によって引 き継がれたが、理化学の研究教育機関もその一つであった。元治元 （1864）年、長崎の医学校・養生所内に理化学校・分析究理所が設 けられたが、幕末の混乱から計画は中断し、結局、明治新政府によ つて慶応 4 年 7 月に理化学校は大阪に移すことが決められた。日本 教育史の倉沢剛は、この頃までに洋式の近代貨幣工場を大阪に建設 することが決まっており、それにあわせて「造幣技術に必要な物理。 科学の研究講習が急務であった。そのためまず第一に、化学所すな わち舎密局を考え」3)たと述べている。舎密局の建設場所は、城 の西側の京橋口御定番屋敷跡に決まり、10月に起工、翌明治 2 年 3 月末には校舎が竣工し、同年 5 月に開校した。舎密局については、 近代建築史の菊池重郎、化学者で科学史家の芝哲夫、京都大学大学 史を調べている藤田英夫らによって、その施設や教育内容について かなり詳しく報告されている”。とりわけ舎密局の建設場所は、菊 池重郎の研究によって確定されたと言える”。これらの研究による と、その校舎は写真 1 にあるように、周囲にベランダをめぐらせた 洋風の建物で、中央部に風見のついた櫓を高く揭げていた。平面は コの字形で、教室が階段状になっているなど、木造ではあったが先 進的な建物であった ${ }^{()}$。西隣には舎密局の教頭・ハラタマの居宅も 新築され、それも写真 3 のように、ベランダをめぐらせた洋風の建 物であった ”。舎密局は早くも明治 3 年 5 月には、大阪理学校に名 称が変わっている。

舎密局の設置が大阪に決まった明治元年暮頃には、城址西部地区 に舎密局を含み他に多くの施設を配した「新大学校」の構想が描かれ ていだ〉。大阪府は明治元年の 10 月付けの「御布告案」で、「此度 追手前に於て新大学校御取建二相成、舎密術を初为英学・仏学・蘭

学・数学・法学等学術御開二相成候」と発表している"”。日本の近 代の公園や博覧会計画の草分け・田中芳男が舎密局の御用掛になつ て、そこで描いた「新大学校」の計画図が残っている。そ扎は、舎 密局などの「学問所」のほか、「園圊」や「遊歩所」、「博物場」な どを含み、西洋式の庭園も併せ持つ先進的なものであった ${ }^{10)}$ 。大 阪城址に、軍事利用に対して、一方で文教施設のかなり大きな構想 が描かれていたことになる。

含密局に続いて、西洋の諸学を教授する洋学校が、明治 2 年 9 月 に淀川の北岸・天満川崎の営縉司庁跡に、生徒寄宿所とともに、仮 のものではあったが設置された ${ }^{11}$ 。高度な理化学を教授する舎密 局に対して、こちらは語学や数学等の普通学を授ける学校で、当初 は大阪府の管轄であった ${ }^{12 !}$ 。同年 12 月、この洋学校は大阪府の管 轄から民部省の管轄に移り、神戸にあった兵庫県洋学校も吸収して、 校舎を城西の島町旧代官邸に移した。明治 3 年 7 月には、東隣にあ った旧裁判所兵部出張所が転出した機会に、その跡を洋学校の教室 に充てたいと管轄者の大学に陳情し、合わせて講堂の建設も願い出

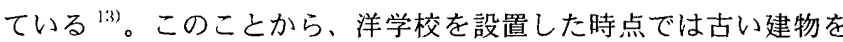
転用し、それだけでは手狭でもあり不十分であったことが伺える。

同年 10 月に、洋学校は大阪開成所と名称が変わり、同時に大阪 理学校すなわち旧舎密局は大阪開成所分局理学所となって、それら 2 校が統合した。この統合を契機として、旧洋学校の狭险な校舎を 改め、「理学校内の空地へ新校舎を建て增し、両校合併して講学を 便に」いするこえが計画された。大阪開成所の新校舎は明治 4 年 6 月に旧舎密局の建物の南側に完成して、7 月に新たに開校し、島 町の旧洋学校校舎は寄宿舎に充てられた。

このように、校舎は次第に整備され、施設の体裁も整えられてい つたが、大阪開成所の名称は落ち着かず、第四大学区第一番中学校、 開明学校、大阪外国語学校、大阪専門学校、大阪中学校など、何度 も改称される。さらに、明治 19 年には第三高等中学校に改称され、 22 年にはついに京都へ移転し、国の管轄する高等教育機関は大坂 城址からはなくなった。

\section{3. 医療施設の設置}

西洋医学の受容史を研究している松田武は、「大阪府仮病院の創 設」司ににおい、明治初年の大阪における近代西洋病院の設置の 
経緯を論じている。本章では、主にそれを参考にして、大坂城址に おける医療施設の設置の様子を見ていく。

慶応 4 年閏 4 月、大阪裁判所は「今度浪花二於て病院御取建二相 成、窮民二シテ疾病療盖不行届之もの共御救助可被為在旨被仰出候 事」と、明治天皇の御沙汰が下ったことを発表している ${ }^{16)}$ 。これ を受けて同年（明治元年）12月に大阪府仮病院が開設され、才ラ ンダ人軍医・ボードインがその長に任命された。しかし、ボードイ ンの着任は遅れ、最初の 2 か月ほどは、舎密局の教頭に就任するこ とが決まり既に在阪していた八ラタマが、彼に代わってその任務に あたった。ハラタマはボードインが長崎にいたころ理化学教育の充 実のために才ランダから呼び寄せた人物であるが、軍医学校の出身

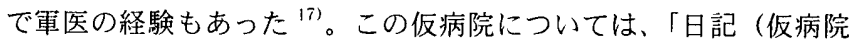
詰所附)」 ${ }^{18)}$ によって、明治元年 12 月 14 日の開設から明治 2 年 2 月 25 日の間の様子を知ることができるが、そこに病院の所在がわ かる記述はない。所在地については：後に正式の大阪府病院が設置 された旧鈴木町代官屋敷とするものや尼崎町の種痘所に置かれたと 推定するものがある ${ }^{1 ! 9}$ 。御沙汰書の発布から設置までの期間の短 さや「仮」とついた名称から考えて、建物は既存のものを転用した と考えられる。松田は、日記の記述内容から、仮病院は「太政官の 意向に沿って大阪府が設立の任にあたり、大阪府兵局の直接管轄す る軍事病院であった」201)としている。すなわちこの病院は、設置 の契機となった病院取建の御沙汰書にあるような市民のための一般 病院ではなく、少なくともその始まりの数ヶ月は、軍事的色彩の濃 い、限られた者を対象とする病院であったと言える。しかし、明治 2 年 7 月 19 日には「今般鈴木町元代官屋敷二於而病院取建相成候 二付、診察・療養請度もの八、朝四ツ時より九ツ時迄之間、勝手二 罷越可申候、尤困窮之ものとも者、同書へ願次第、施薬をも遣し候」 21)との布令が出されており、この頃には市民も利用できる施設に なっていたことが分かる。

明治 2 年 2 月にボードインが着任して、大阪府仮病院は大坂城址 外の上本町の大福寺に一時期移転した ${ }^{22)}$ 。ここでは寺の庫裹を利 用して治療と医学伝習が行われたが、同年 7 月には大坂城址内の鈴 木町の代官屋敷跡に移り、正式に大阪府病院が発足した。しかし、『近 代年来記』の明治 2 年 10 月頃の記録の中に、「鈴（木）町代官も 異国の医師宿に相成、いたわしき事成」 ${ }^{233)}$ とあるように、建物は まだ旧幕時代の建物を転用して使っていたと考えられる。同年 11 月には西側隣地にようやく建物が新築され、名称もこのとき大阪 府医学校病院之変わった。その建物群は写真 2 に見るもので、菊池 重郎によつてその施設の先進性や意義について既に報告がある ${ }^{2-11}$ 。 第三高等学校の学校史『史料神陵史』でも、「医学校舎は、教場并 に解剖場等は先年蘭医ボードインの差図に依って新築したもので可 成壮麗であったといは执る」こミとある。

医学校病院は、開校の翌年、大学の管轄となり、明治 5 年 8 月に は第四大学区医学校と改称されたが、まもなく同年 9 月に学制改革 によって廃校となった。旧医学校の建物は、いつたん第一番中学校 に引き継がれ、その後は明治 6 年 8 月に設置された大阪師範学校の 校舎として使われた ${ }^{2(i)}$ 。

\section{4. 軍事施設の設置}

兵部大輔・大村益次郎は、陸軍の主要な機関を首都東京ではなく
大阪に集中させることを企図した。大村はその計画を進めるために 来阪の途上、明治 2 年 9 月に京都で襲われ命を落としたが、その遺 志は引き継がれ、兵部省大阪出張所役庁、兵学寮、造兵司、軍事病 院などの施設が二の丸・本丸を中心に設置されていった 27 。

兵部省（後の陸軍省・海軍省）は、明治 2 年 7 月に大阪出張所を 設置し、その役庁には、焼け残っていた千貫櫓と多聞櫓があてられ た。それらは大手ロの城門に付属して今も残る櫓だが、「空は硝石 張りにして高卓椅子と改め」て使われた ${ }^{2 \times)}$ 。

兵学寮は陸軍幹部の養成機関で、後の陸軍士官学校にあたり、青 年学舎とも呼ばれた。『陸軍省沿革史』によれば、明治 2 年 9 月に 京橋口門内に設立された。しかし、建物は明治 3 年 1 月の段階でも完 成していなかった ${ }^{29)}$ 。完成した建物は、写真 4 のように、広い中. 庭をもつロの字形の洋式の建物で、完全に西洋式の生活や軍隊の訓 練が行える施設になっていた ${ }^{30)}$ 。明治 3 年 4 月に、京都河東操練 所を移して、下土官を養成する教導隊が兵学寮内に設置され、5 月

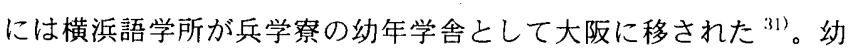
年学舎の設置場所については、「城内の櫓をもってあてられ」 ${ }^{22)} た$ や、「御多門の横手」331) とするものがあるが、いずれにしても二の 丸大手口付近に設置されたと推定できる。しかし、明治 4 年 10 月 には兵学寮は東京へ移転し、それにあわせて教導隊、幼年学舎も移 転して、一時期、大阪に集中していた陸軍士官の養成機関は大坂城 址からなくなった。

士官だけではなく多数の兵隊が日本各地から大阪に集められ、そ のための駐屯所や訓練施設が主に城の南部に設けられた。明治 5 年 5 月発行の『大阪市中地区町名改正絵図』を見ると、「兵隊営」や 「砲隊営」と記された区画があり、砲隊営の区画にはコの字の平面形、 なまこ壁風の外観意匠で北面の中央に玄関ポーチを持つ西洋風の建 物の絵が描かれている。それは写真 5 の建物を描いたものである。 玉置豊次郎によると、明治 5 年 5 月発行の上記の地図は、それ以後 に定められた新町名等が記入されていることから、実際には明治 8

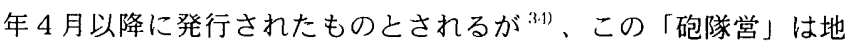
図に依らずとも、他の文献資料に依っても明治 5 年 4 月に竣工した 砲兵第 4 大隊の兵営であると特定できる ${ }^{3}$ (i)。

造兵司とは官営の兵器工場のことである ${ }^{331}$ 。明治 3 年 2 月に設 置が決まり、3月には場所が城の北東部の米倉跡に定められた。4 月には青屋口門内中仕切元番所に仮庁が設けられ、5月には仮の木 造工場が竣工して、6月には事務所を仮庁からその仮工場に移転し ている。本格的な工場施設は、明治 $5 、 6$ 年頃から順次竣成してい つた。名称は、明治 4 年 7 月に大阪造兵司へ、翌 5 年 2 月には大砲 製造所と変わり、広く知られる大阪砲兵工廠という名に変わつたの は明治 12 年のことである。

大阪軍事病院は、大村益次郎の上申にもとづき、彼の死後になる が、明治 3 年 1 月に認可された。軍医学校が併設され、当初は、前 章で見た大阪府病院からボードインや緒方惟準らの多くのスタッフ が移り運営にあたった。発足時は京橋前之町の旧東町奉行所を使用 していたとされるが、大阪府医学校病院（旧鈴木町代官屋敷）の東 隣に置かれたとする説もある ${ }^{3 i 。}$ 。明治 4 年 2 月には城内玉造門内 に、写真 6 の建物が竣工している。菊池重郎の研究によれば、分棟 式配置の近代的な病院で、ボードインが大阪府医学校病院の時以上 に関与したとされる ${ }^{3 *}$ 。 
『近来年代記』に、明治 4 年 9 月 22 日に明治天皇の誕生日を祝 って市民に城中の見物が許されたとある。そのときのこの著者の感 想に、「異国作りにして其美成事云計りなし。妙々立方なり」 ${ }^{339)}$ 之 ある。具体的にどの建物を指しているのかは書かれていないが、こ の頃までに城中には兵学寮や大阪軍事病院が竣工しており、それら の目新しい洋風建築を見ての感想であろう ${ }^{10) 。 ~}$

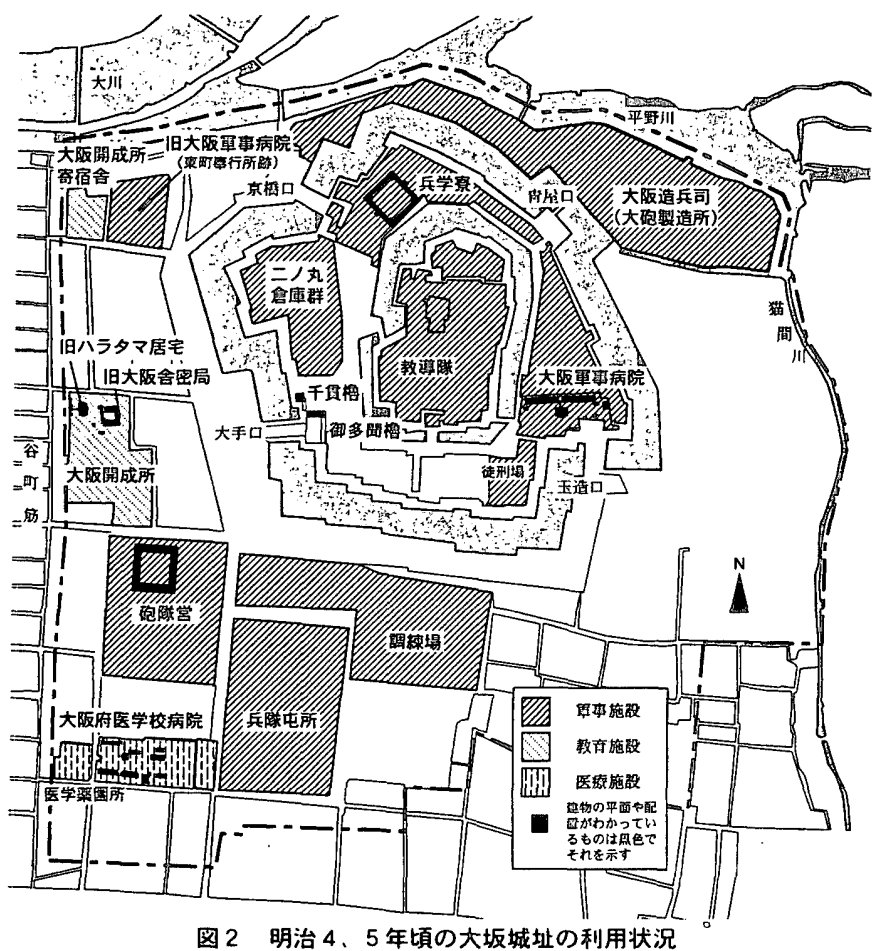

表 1 明治初年の大坂城址における諸施設設置状況
明治 4 年 7 月の廃藩置県と同時に、日本の軍制は大きく変わった。 大阪に設置されていた陸軍の中枢機関は、ほ之んどが首都東京へ移 転して軍事面でも中央集権が進められた。全国は4つに分けられ、 大阪には大阪鎮台本部が設置され、陸軍の西日本の拋点と位置づけ られた。その後、大坂城址にはそれに応じた軍事施設や関連施設が さらに設置され、一段と車事拠点としての色彩を濃くしていった。

\section{5. 諸施設の設置と分布}

明治初年の $1 、 2$ 年のうちに、大坂城址は大きく変貌し始めた。 明治に元号が変わって 1 か月後には、早くも京橋口御定番屋敷跡で 舎密局の工事が始まり、同年の 12 月には天皇の御沙汰にもとづい て大阪府仮病院の活動が古い建物を転用して始まった。明治 2 年に は、舎密局が竣工し、兵部省の役庁が焼け残った大手口の城郭の一 部に設置され、堀に囲われた二の丸の北西部では兵学寮の新設工事 も始まっていた。明治 3 年にはその兵学寮が竣工し、旧三の丸の南 西端には大阪府医学校病院の建物が新たに完成に向かっていた。明 治 4 年には二の丸南東の玉造門内に大阪軍事病院が竣工し、造兵司 の工場が青屋口の北東部に、また兵隊の駐屯所や訓練所が旧三の丸 の南部にそれぞれ完成あるいは建設中であった。

図 2 は、明治 4，5年における大坂城址の利用状況を地図上に示し たものである。これを見ると、軍事の中枢的施設は堀に囲まれ防御 性の高い本丸や二の丸に、兵器工場は隔離と水運の図れる北東外縁 部に、多くの一般兵が寝起きする駐屯所や訓練所は、もともと武家 屋敷が多く敷地の広い旧三の丸南部に、そして教育施設や医療施設 は一般市街地に接する旧三の丸の西部外周部にと、それなりの配置 の原則にしたがって設置されていることがわかる。舎密局の御用掛 田中芳男が明治元年の暮れ頃「新大学校」の構想を描いたのは、西 凡例：〈〉内は所在地を示す。【】内は管轄を示す。

\begin{tabular}{|c|c|c|c|}
\hline & 教育施設 & 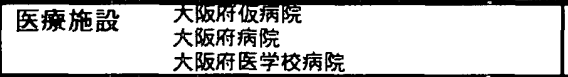 & \begin{tabular}{|c} 
軍事施設 \\
大阪軍事病院
\end{tabular} \\
\hline 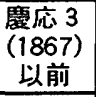 & 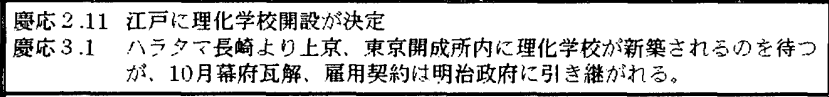 & & \\
\hline $\begin{array}{l}\text { 鹿応 } 4 \\
\text { 明治元 } \\
(1868)\end{array}$ & 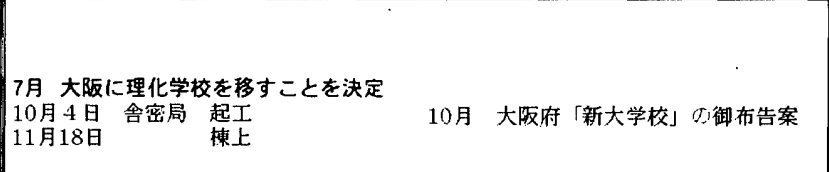 & 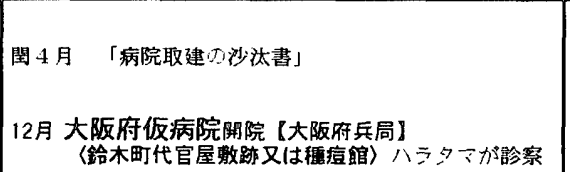 & \\
\hline $\begin{array}{l}\text { 明治 } 2 \\
(1869)\end{array}$ & 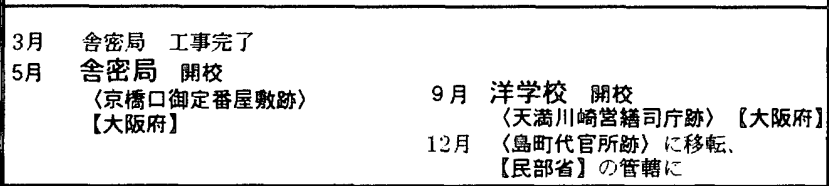 & 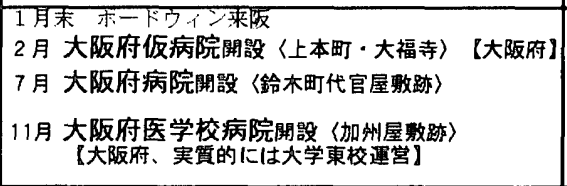 & \\
\hline $\begin{array}{l}\text { 明治 } 3 \\
(1870)\end{array}$ & 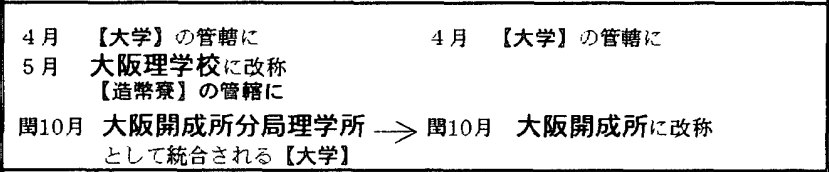 & 2月【大学】の管轄に & $\begin{array}{l}1 \text { 月 大阪軍事病院 } \\
\text { 嘔可〈京橎前之町 } \\
\text { 東町奉行所跡又は } \\
\text { 大阪医学校病院東 } \\
\text { 隣〉【兵部省】 }\end{array}$ \\
\hline $\begin{array}{l}\text { 明治 } 4 \\
(1871)\end{array}$ & $\begin{array}{c}7 \text { 月 〈旧全密局南側〉に新校舎竣工 } \\
\text { L.移転。旧校舎は奇摍舎に。 }\end{array}$ & 7月 大阪府医学校付属大阪病院に改称【文部省】 & 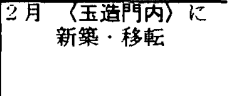 \\
\hline $\begin{array}{l}\text { 明治 } 5 \\
(1872)\end{array}$ & $\begin{array}{l}8 \text { 月 第四大学区第一番中学校 } \\
\text { に改称 }\end{array}$ & $\begin{array}{l}8 \text { 月 第四大学区医学校に改称 } \\
9 \text { 月 学制改革、魔校となる }\end{array}$ & \\
\hline $\begin{array}{l}\text { 明治 } 6 \\
(1873) \\
\text { 以降 }\end{array}$ & $\begin{array}{l}\text { M6.4 開明学校に改称 } \\
\text { M7.4 大阮外国語学校に改称 } \\
\text { M7.12 大阪英語学校に改称 } \\
\text { M12.4 大傮門学校に改称 } \\
\text { M19 移転 }\end{array}$ & $\begin{array}{c}\text { M6.8 大阪府医学校病院の建物は, } \\
\text { 大阪師箸学校として利用 }\end{array}$ & \\
\hline
\end{tabular}


部外周部に位置する舎密局・大阪開成所の敷地とその北側の空白の 土地を用地としてであった。それらの設置計画は必ずしも総合的に なされたものではないが、上記の配置原則に見るように、ばらばら になされたものでもない。軍事施設は国の機関である兵部省が、ま た教育と医療施設は大阪府が、それぞれ計画し設置した。しかしこ の時期、国や大阪府といっても、安定し自立した機関として成立し ていたわけではなく、大阪府の知事や役人は新政府によって任命さ れ、そのもとに国と府は連携し役割分担をしていたのである。何よ り、この頃はまだ、新政府が手中に収めた大坂城址の土地に十分な 余裕があり、大まかな土地の使い分けによって、同時並行的に建設 が進めていくことで特に問題が起きることはなかった。また、施設 の設置主体や管轄は異なっていても、数少ない外国人指導者が対岸 の造幣寮も含めてそれらの設置や運営にかかわっていた。舎密局の 教頭に就くことが決まっていたハラタマは舎密局の建設や造幣寮や 病院の運営にもかかわり、ボードイン忧大阪府医学校病院と軍事病 院の建設に携わった。生徒も講義を聴講するために他の施設へ通い もしている。どの施設でも西洋技術の修得と人材の育成が急務であ ったのである。

\section{6. 諸施設の変遷}

表 1 は、明治初年に大坂城址に設置された諸施設の設置と変遷の 状況を系統化して年表に示したものである。いずれの施設も短期間 のうちに激しくその管轄や名称などを変えていることがわかる。教 育・研究施設の端緒となった舎密局は、旧幕府の交わした契約を明 治政府が引き継いで実現したものであり、明治 2 年 5 月に開校して いるが、 1 年後の 3 年 5 月には早くも大阪理学校に改称し、管轄も 大学に移り造幣寮のもとに属している。舎密局の建設に当たっては、
当初「新大学校」の構想も存在したように、舎密局と洋学校や大阪 府医学校病院は、ともに大阪府のもとで運営され関連を持っていた。 しかし、これらの施設も、明治 3 年にはいずれも府の管轄からはず れ、一括して翌年に創設された文部省の管轄のもとに移っている。 もともとは国がつくるべき施設も、まずは大阪府のもとで建設し、 国の体制の整備とともにその所轄を変え、それぞれの位置に収まっ ていったと見ることもできる。二の丸や本丸にあった兵学嗉や教導 隊などの軍の教育機関も、明治 4 年にはすべて東京に移り、兵部省 出張所も地方の軍事拋点である大阪鎮台本部へと変わる。いずれも、 国の先端的な施設から、国の管轄の下での地方の中心的な施設へと その役割を変えていったのである。

\section{おわりに}

明治初年に大坂城址に設置された諸施設は、激動する国内情勢と 欧米列強の妿威のもとで、新政府が国の近代化のために急いで整備 しようとしたものであったが、その建設が進んでいる最中にも、そ れらを取り巻く環境は激変していた。明治元年 9 月には天皇が東 京に移り、翌 2 年には東京遷都となり、版籍奉還も進み、明治 4 年 には廃藩置県が断行されて、いよいよ東京を中心とする中央集権的 な体制へと進んでいった。この間に、大坂城址に設置されたばかり の施設もその影響を直接に受け、それらの役割・内容や管轄・名称 などを変えていった。朝令暮改とも言える変更は、統治の体制が変 わる変革期であったことに因るが、体制が安定していない中でも、 可能なところで使える手段を使って、近代化を早急に進めていこう とした結果のあらわれであった。明治初年、大坂城址に旋風のよう に巻き起こつた時代を先駆ける活涗は、一気に沈静化していったと 言える。しかし、設置された施設はその地位や性格を変えながらも、

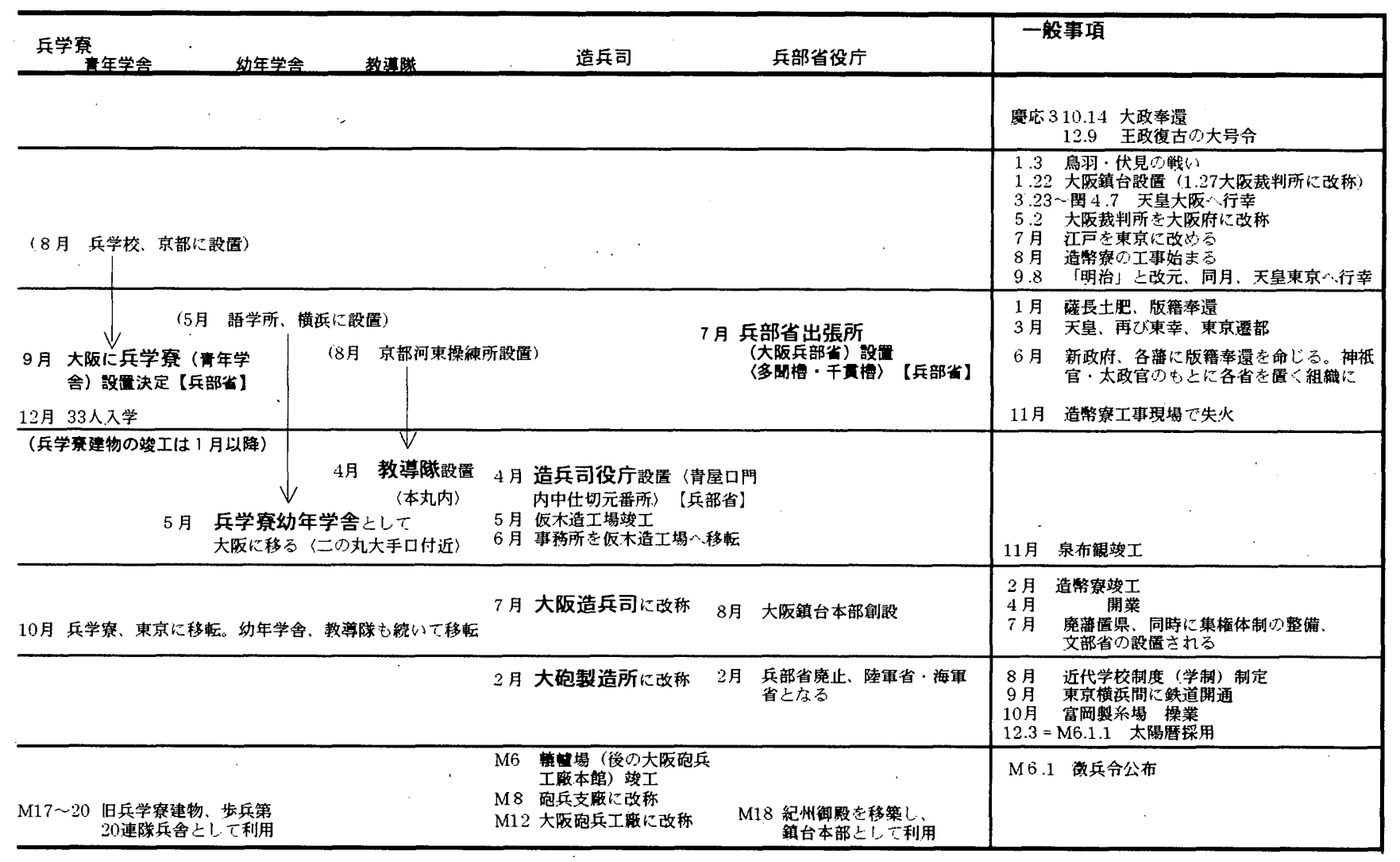


いずれも後に引き継がれ、大阪の発展に寄与するものになっていつ た。大坂城址は、明治初年に教育、医療と軍事の諸施設が設置され、 この時すでに以後に来るこの地の市民利用と軍事利用の併存と競合 の原点をかたちづくっていたと言えるのである。

\section{注}

本稿は、橋寺知子、北野克則、川道麟太郎：明治初年に大坂城址に建てら れた建物についてー近代の大坂城址の利用に関する研究一、平成 13 年度日 本建築学会近畿支部研究報告集、計画系、pp. $909 \sim 912$ 、平成 13 年 5 月、 および橋寺知子、川道碳太郎：明治初年の大坂城址の土地利用と建物につい て一近代の大坂城址の利用に関する研究一、日本建筑学会大会学術講演梗概 集、F-2、pp. $217 \sim 218 、 2001$ 年 9 月などをもとに、加筆、修正を加え 構成したものである。

1) 内田九州男 : “大阪城研究の歩み”(『大坂城と城下町』、思文閣出版、 2000 年）に上机ば、三の丸の範囲については既往研究でもいくつかの説が あり、練かな点で差異はあるが、ここで示した範囲と大きくずれることはな い。東側の境界・猫間川は三の丸ではなく鴾構の境界にあたるが、近代の利 用がそこに及ぶところから、ここでは猫間川までを一体に扱うこととする。 2）幕末から明治初期の教育に関しては、倉沢剛：『学制の研究小、講談社、 昭和 48 年をはじめとする研究があり、発足間もない明治政府がとった教育 施策が明らかになっている。本論で述べる舎密局や洋学校、医学校の発足過 程については、倉沢の同書第 2 章第 7 節「大坂における大学の企画」に多く を負っている。

3) 同上書, p. 88

4) 菊池重郎：“含密局の再発見一姿を消したある建物との対話”、『自然』、 1974 年 8 月号、 pp. $58 \sim 70$ 、芝哲夫: “大坂舎密局史”、『大阪大学史紀要』、 第 1 号、1981 年、pp.33 47、藤田英夫: 『大阪舎密局の史的展開一京都 大学の源流』、思文閣出版、平成 7 年等で、舎密局の歴史的意義等も含めて 詳しく述べられている。

5) 戦前期より、記念碑の位置と実際の場所が異なることは指摘されていた が、菊池重郎が同上書において、その位置について詳紐に検証している。

6 ）舎密局の平面については、藤田英夫：前掲書（注 4）において、「大坂 開成所全図」等の図を取り上げてよく整理されている。

7) ハラタマについては、芝哲夫:『オランダ人の見た幕末・明治の日本』、 荣根出版、1993 年に詳しい。同書揭載のハラタマの書簡から、住居の間取 りや生活の梯子をうかがうことができる。

8）菊池重郎：“大阪城西諸施設に関する田中芳男文書について 特に舎密 局の位置ならびに園囷計画”、『蘭学資料研究会研究報告小、第 282 号、1 974 年 5 月、pp.1 〜 11、および前揭書（注 4) において、明治初年に描かれた 構想について、詳しい分析がなされている。

9 ）神陵史資料研究会編：『史料神陵史一舎密局から三高まで一』、神陵史 資料研究会、平成 6 年, p. 68

10）菊池重郎：前揭書（注 8)

11）大阪府史編集室編：『大阪府布命集一』、大阪府、昭和 46 年、p.196 なお洋学校の設置時期については、倉沢㓮は前揭書（注2）において、洋学 校督務に就いた何礼之助の建言書の日付が 10 月であることから「開設は少 くとも明治二年十月以後とせねばならぬ（p.99）と述べている。

12）倉沢剛：前掲書（注 2)、p.91

13）前掲書（注 9$) 、 p .98$ 。なお、舎密局から京都へ移転するまでの経緯に

ついては、同書及び藤田英夫 : 前揭書（注 4）に詳しい。

14）前揭書（注 9 )、p.128

15 ）松田武: “大阪府仮病院の創設”、『大阪大学史紀要』、第 1 号、1981 年 5 月、 及び第 2 号、1982 年 5 月

16）前揭書（注 11）、p.41

17）ハラタマの来歴については、芝哲夫の前掲書（注て）に詳しい。

18）石橋栄達：“大阪付仮病院の開設は明治元年末なり”、『臨床医報小、第 568 号、昭和 17 年 1 月 10 日によると、この日記は他の書類とともに緅ら れて三高に保存されていたもので、松田武：前揭書（注 15）に翻刻されて いる。『史料神陵史』にも引用されているが、原本遗失」との注記がある。 19）緒方个㐸郎は、“更に「浪華仮病院並初代大阪医学校を語る」を補う”、 『臨床医報』、昭和 17 年 1 月 10 日で、「明治元年の末より既に鈴木町代官屋 敷を病院の仮設地と定めありて同屋敷に普請を加え工事の一部落成を十二月
十四日に見たるに非ずやと推定する」と言う。また松田武は前揭書（注 15） で、尼䗁町の種痘所が大阪府仮病院となったのではないかと推測している。 20）松田武：前掲書（注 15）、p.66

21）前揭書（注 11）、p.184

22）大阪府仮病院については、大福寺仮病院や浪華仮病院等の呼び方も見 られる。注 18 の「日記」には、2月25日の闑に「一、上本町八丁目寺町 大念寺内教席借受の儀、御許容相成に付」とあるが、これは大福寺の誤りで あることが緒方ケ㐸郎や松田武によって指摘されている。また、緒方佽郎 の手記 “浪華仮病院及初代大阪医学校を語る”、関西医事』、第 449 号〜第 455 号、昭和 14 年 9 月 2 日 10 月 14 日では、大福寺での仮病院や鈴木町 代官屋敷跡へ移転してからの医学校の様子が詳細に描かれている。

23）大阪市史編筑所編:『近来年代記下』、大阪市史史料第二輯、昭和 55 年、 p.147。『近来年代記』は、筆者末詳ではあるが、幕末から明治中期までの 大阪の出来事を書き留めたもので、庶民生活の面から捉えた世相史である。 24）菊池重郎：“明治初年の大阪における病院建築について 特に城内の大 阪軍事病院の建筑”、『日本建築学会大会学術講演梗概集』計画系、1983 年、 pp.2583〜2584で言及さ机ている。

25）前揭書（注 9 )、p.191

26）同上書、p. 252 。医学校廃校後、明治 6 年 2 月に大阪府によって新たに 大阪府病院が津村別院（北御堂）に設置され、医学教育もなされた。

27）明治初年に大坂城址に設置された陸軍施設に関しては、小田康徳 : “大阪陸軍所の創設とその展開”、『大阪の歴史』第 8 号、昭和 58 年 3 月、 pp. $1 \sim 23$ に詳しい。

28）梅溪昇：「大阪兵学寮に関する風文書についてい、『ヒストリア』、第 56 号、昭和 45 年 9 月、p. 55 。また、福良竹亭 : “兵部省時代の大阪城”、『上 方小 11 号、昭和 6 年 11 月、p.91 では、千貫櫓に兵部省、多聞櫓に会計部 があったと、当時兵部省に勤めていた野々村繁藏の回想が揭載されている。 29）策原宏：『陸軍創設史 フランス軍事顧問団の影』、リブロポート。 1983 年、pp. $293 \sim 294$ で、兵学察の設立日を確定する基本文書はなく、『陸 軍省治革史』と当時勤めていた軍人達の自叙伝等での記述では食い違う点が あると指摘されている。篠原は、「基本資料を欠いているのは、大村派が実 績づくりのため公文書をあまり作らなかったのか、あるいは後で大久保派に よって除かれたためか、今後の究明が待たれるところである」と記している。 30) 兵学寮の間取りについては、柳生悦子が『史話 まぼろしの陸軍兵学寮』、 六興出版、昭和 58 年で、当時の日記の記述から推測し示している。しかし、 柳生の推定にはかなり問題もある。その点については、兵学尞に関する詳し い報告とともに、別稿で触扟る予定である。

31）福良竹亭：前揭書（注 28）では「本丸の中に教導団が出来、それが後 になり教導団の退いた後へ師団司令部や会計部が移って事務を取ることにな りました」とある。

32) 田部正壮：“兵学寮から日露戦争迄”、『偕行社記事』754 号、p.198 33) 福良竹亭：前揭書（注 28）、p.92

34）玉置豊次郎：『大阪建設史夜話』、大阪都市協会、昭和 55 年、p.344

35 ）砲兵第四大隊の前身・大阪砲兵隊は明治 3 年 11 月に編成された。兵営 の竣工年等については『東區史』、第 2 巻行政篇、昭和 15 年、p.1023 参照。 36）造兵司については、『大阪砲兵工廠沿革史小、大阪砲兵工廠、1902 年 に明治 10 年頃以降の配置図等の資料があるが、設置当初の建物について は詳しくは述べられていない。なおこの史料は久保在久編：『大阪砲兵工廠 資料集』、日本経済評論社、1987 年として復刻されている。広川禎秀：“大 阪砲兵工廠「本館」の建築年代とその歴史的意義”、『歴史科学』、第 86 号、

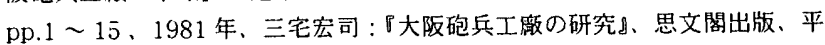
成 5 年、等の研究を参考とした。

37）緒方富雄：“「短命であった大阪舎密局」補遗一四つの手写資料の追加”、 『蘭学資料研究会研究報告』、第 278 号、1974 年 1 月では、大阪府医学校病 院（旧鈴木町代官屋敬）の東隣に置かれたとある。

38) 菊池重郎：前揭書（注 24）。また、大阪府仮病院、大阪府医学校病院之 大阪軍事病院の関係については、松田武 : 前揭書（注 15）に詳しい。

39）前揭畫（注 22）、p.151

40）柳生悦子：前揭書（注 30）などで、この記事を、兵学寮を見ての記述 としているが、その時点では大阪軍事病院もでき上がっており、必ずしも兵 学寮と特定することはできない。

(2002年 9 月 10 日原稿受理， 2003 年 3 月 20 日採用決定） 